\title{
SELECTED LEGAL CONDITIONS VALID BY TRANSPORT OF DANGEROUS GOODS BY RAIL IN EUROPEAN UNION
}

\author{
Lucia Knapčíková \\ Technical University of Košice, Faculty of Manufacturing Technologies with a seat in Prešov, Bayerova 1, 080 01, \\ Prešov, Slovakia, lucia.knapcikova@tuke.sk \\ Michal Balog \\ Technical University of Košice, Faculty of Manufacturing Technologies with a seat in Prešov, Bayerova 1, 080 01, \\ Prešov, Slovakia, michal.balog@tuke.sk
}

Keywords: rules, EU, dangerous goods, rail

Abstract: The purpose of transport of dangerous by rail is to harmonise the rules applicable to the national and intracommunity transport of dangerous goods by rail. Harmonisation of the rules makes it possible to remove obstacles to the free movement of goods between Member States with regard to transport equipment. Such transport will therefore be carried out under the best possible safety conditions. In EU legislation the application of RID rules is extended to domestic transport. In addition Directive 96/35 on the appointment and vocational qualification of safety advisers for the transport of dangerous goods by road, rail and inland waterway requires employers whose employees load, transport or unload dangerous goods in significant quantities to appoint, a special vocationally certified 'adviser' to monitor compliance with the transport by road, rail and inland waterway requirements.

\section{Introduction}

In EU railway "substance safety" is defined by the International regulation concerning the carriage of dangerous goods by rail (RID, appendix $\mathrm{C}$ of the COTIF international convention) which is derived from the UN regulation model for TDG and from the Global Harmonized System for classification and labeling of chemicals [1]. RID rules include: classification of dangerous substances following their physical properties, hazards' types and intensities; design of packaging, containers and tanks; specific provisions for loading/unloading operations of containers and tankwagons; handling and disposal of packages and containers on wagons as well as labelling of packages and wagons marking [1]. Also RID defines and allocates responsibilities to competent bodies and authorities concerning the correct implementation and control of RID rules. In particular competent authorities are identified for tests, controls, maintenances and inspections applicable to the tank part of the tank wagons.

The EU framework Directive on inland TDG (2008/68) defines the application scope in the EU legislation of RID (rail TDG), ADR (road TDG) and ADN (waterways TDG), and sets common conditions for transport derogations or additional restrictions in EU-MS [2]. In EU legislation the application of RID rules is extended to domestic transport. In addition Directive 96/35 on the appointment and vocational qualification of safety advisers for the transport of dangerous goods by road, rail and inland waterway requires employers whose employees load, transport or unload dangerous goods in significant quantities to appoint, a special vocationally certified 'adviser' to monitor compliance with the transport by road, rail and inland waterway requirements. In the Fig.1 it is to see the scope of RID Application.

\section{Legal conditions valid by transport of dangerous goods by rail}

The Regulation concerning the International Carriage of Dangerous Goods by Rail (RID). RID was drawn up by the intergovernmental Organisation for International Carriage by Rail (OTIF), comprising 46 member countries. It is established on European territory through European directive 2008/68/EC, and transposed into French law by the Ministerial Order known as the "arrêté TMD", or "TDG Order". [3] Similar transposition exists in each Member State. This Regulation applies to international traffic. Directive 2008/68/EC transposes RID into the EU's internal law, including for national transport. OTIF and the Commission have put in place the necessary coordination. As a result of coordination work between the UNECE in Geneva and OTIF, the provisions on the carriage of dangerous goods by rail are also harmonised with the provisions for road transport (ADR) and inland waterways transport (ADN). The RID (international railway transport regulation for hazardous goods) regulation specifies the conditions under which selected hazardous goods must be transported. More or less 3,500 products are approved with specific identification and coding [4],[5]. 
Lucia Knapčíková; Michal Balog

The HG Task Force of the United Nations regularly releases new versions of their recommendations for dangerous transport, which take into account recent technical progress, appearance of new dangerous matters and new building materials, the needs for the modern systems of transport and, initially, the requirements for safety of people and property and environmental protection [1]. Each transport mode covers particular constraints, there it exists particular international legislations adapted from these UN recommendations (ADR for road, IMDG for the sea transport, IATA for the air, RID for railway). These international texts are also introduced in the national legislation (in France, the "Arrêté RID" for rail transport) [2].
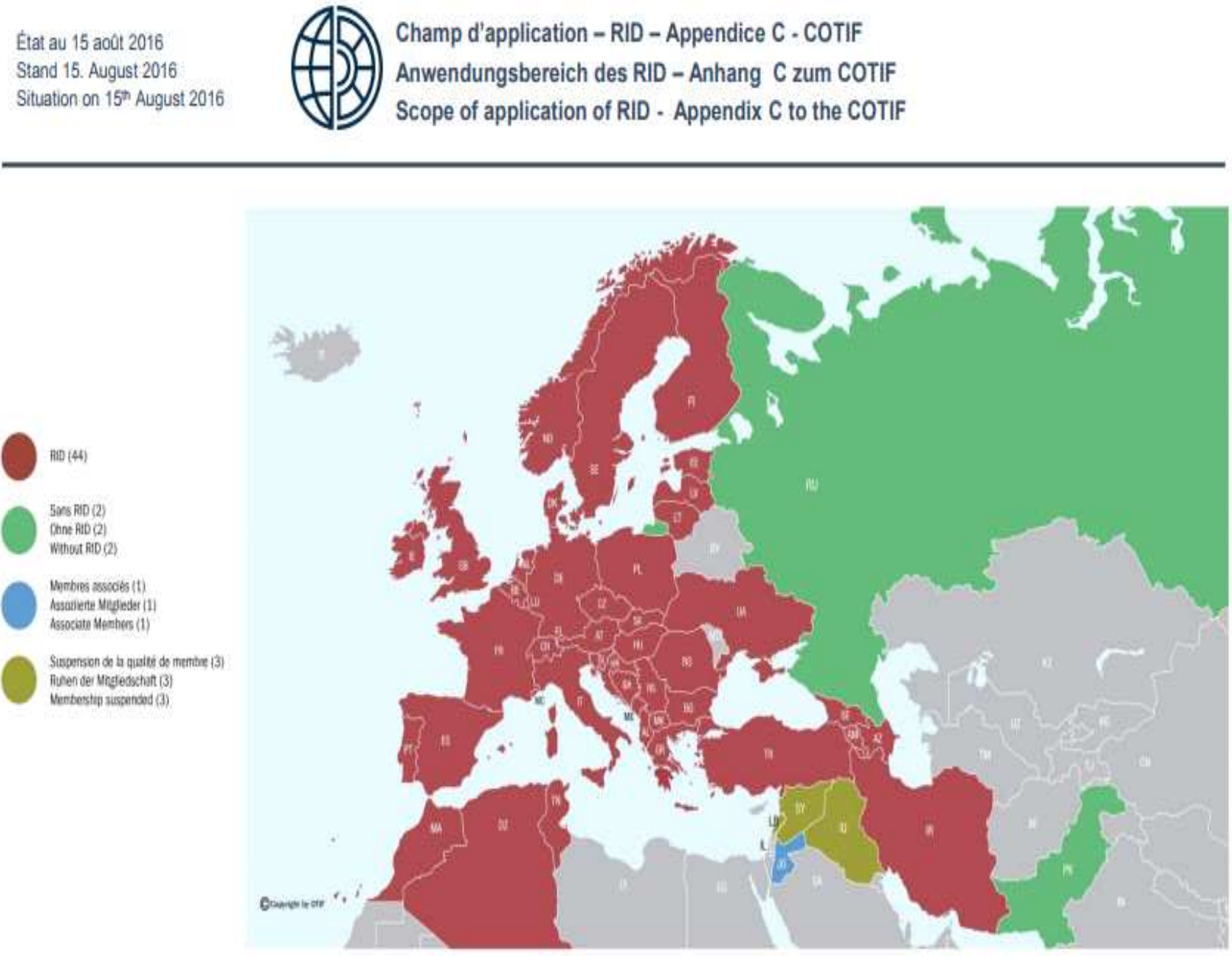

Figure 1 Scope of RID Application [1]

\subsection{EU railway legislative processes}

There are three Directives that directly impact on the transport of dangerous goods: 2008/68/EC Directive of European Parliament and the Council of 24 September 2008 on the Inland Transport Directive of Dangerous Goods [3]. This Directive requires Member States to apply the provisions of the RID, ADR and AND to all transport operations in the Community domestic and international. The Directive also provides the Commission with powers to permit derogations from the international modal provisions after consulting the Regulatory Committee on the Transport of Dangerous Goods (TDG Committee). This committee meets about twice a year (meetings are called by the Commission) and is attended by Member States and industry representatives. Only Members States' representatives can vote and the procedure will depend on the so-called "comitology procedure" applied [4],[6].

2010/35/EU Directive of European Parliament and the Council of 16 June 2010 on transportable pressure equipment. This Directive replaced an earlier version. It is not relevant to this study. 95/50EC Council Directive on uniform procedures for checks on the transport of dangerous goods by road [2]. 
Lucia Knapčíková; Michal Balog

\subsection{Rules related to transport safety}

The EU railway 'transport safety' is regulated by the EU Railways Safety Directive. This Directive defines the roles and the responsibilities for safety management, improvement and development of the EU railway transport system. Transport of dangerous goods is part of the Directive's application scope which also includes requirements for common safety targets (applicable safety levels) and the prevention of serious accidents. From technical perspective the 'transport safety' of Community railways is also related to the Technical Specifications for Interoperability (TSI), which takes into account the principles of the Railway Safety Directive [2],[3],[4].

In particular, the requirements of the freight wagon TSI apply to the wagon part of wagons carrying dangerous goods, similarly to other freight wagons. Thus, a full set of requirements for 'transport safety' is defined by these directives and responsibilities for control of design, construction, placing in service, upgrading, renewal, operation, maintenance and safety management of freight transport, including dangerous goods wagons, are defined. Additional requirements having an impact on the technical specifications of wagons and specific to DG requirements are not in the TSI but only in the RID [5].

Finally both 'substance safety' and 'transport safety' influence the overall safety of railway transport as well as the technical compatibility and the performance of EU railway system [6]. This is why it is so important to ensure a good consistency between EU legislation and the RID provisions. The United Nations has played a pivotal role in the transport of dangerous goods since 1953 (see above) the Economic and Social Council of the UN has established a number of regional commissions and acts as a coordinating organisation for specialist bodies of which the following have a direct interest in the transport of dangerous goods:

- ECE (Regional Commission),

- IMO (Specialised agency),

- ICAO (Specialised agency),

- IAEA (Specialised agency).

In addition, the UN Committee of Experts on the Transport of Dangerous Goods (TDG) and on the Globally Harmonized System of Classification (GHS) and Labelling of Chemicals (UNCoE) is an Expert body appointed by ECOSOC [6]. The committee has two sub committees, one responsible for TDG and one for GHS. The membership of the two committees is different and this report only addresses the TDG. The UNECE provides the secretariat for the whole body (UNCoE, TDG and GHS) on behalf of ECOSOC [4],[5],[6].

\section{Conclusions}

Fuller details of the legislative process are given in "The ABC of European Union Law" published by the EU Publications Office. The European Commission makes proposals for legislation but decisions are made by the Council and the Parliament.

\section{Acknowledgement}

This paper is part of a project that has received funding from the European Union's Horizon 2020 research and innovation programme under grant agreement No. 723274 .
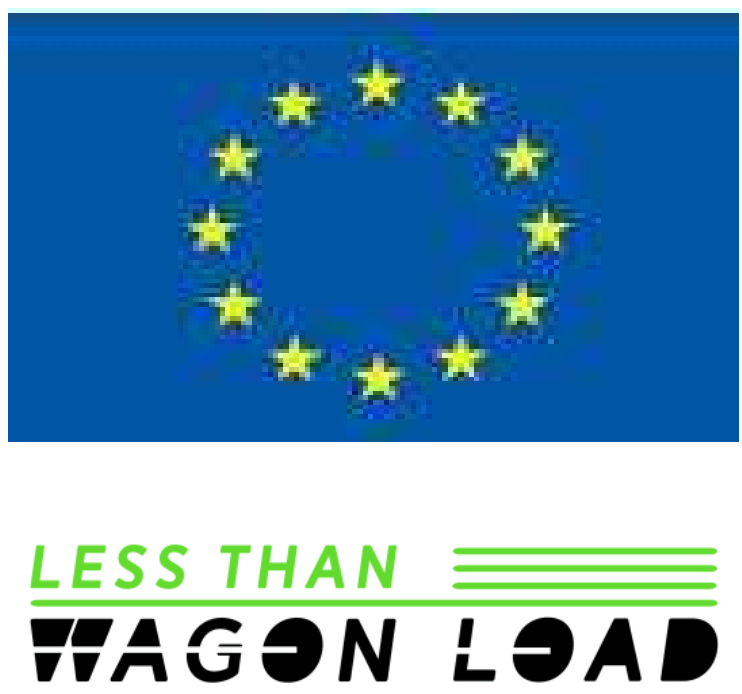

http://www.lessthanwagonload.eu

\section{References}

[1] Intergovernmental Organisation for International Carriage by Rail, Available: http://otif.org/en/?page_id=17, 2017.

[2] Recognition of hazardous goods. Available: http://europa.eu/rapid/press-release_IP-09-

1167_en.htm, 2017.

[3] Rail freight transport in the EU: still not on the right track, Special Report, 8/2016, Available: https://www.eca.europa.eu/Lists/ECADocuments/SR1 6_08/SR_RAIL_FREIGHT_EN.pdf, 2016.

[4] European Railway Agency, Available: http://www.era.europa.eu/Document-

Register/Documents/TO\%20DE\%20error\%20in\%20 WAG\%20TSI.pdf, 2009.

[5] Rail freight transport in the EU: still not on the right track, Special Report, Available: https://www.transportenvironment.org/sites/te/files/Eu 
ropean $\% 20$ Court $\% 20$ of $\% 20$ Auditors $\% 20$ Presentation. pdf, 2006.

[6] COMMISSION REGULATION (EU) No 321/2013 of 13 March 2013 concerning the technical specification for interoperability relating to the subsystem 'rolling stock - freight wagons' of the rail system in the European Union and repealing Decision 2006/861/ECCOMMISSION REGULATION (EU)

\section{Review process}

Single-blind peer reviewed process by two reviewers. 